\title{
PENGUKURAN NAICU PADA SEKTOR INDUSTRI PENGOLAHAN BERDASARKAN DUAL COST CAPACITY UTILIZATION
}

\author{
Endy D Tjahjono, Jardine Husman, Desthy Sianipar ${ }^{1}$
}

\begin{abstract}
A b s tract
Following the study on the measurement of capacity utilization of manufacturing industries in Indonesia (Tjahjono, Husman, and Sianipar (2005)), this paper estimates the level of NAICU, Non-Accelerating Inflation rate of Capacity Utilization. According to this concept, NAICU is the level of capacity utilization consistent with stable inflation. If the level of capacity utilization exceeds the level of NAICU, then there will be pressure on inflation to accelerate. On the contrary, there won't be acceleration on inflation if the level of capacity utilization below the level of NAICU. Using the threshold method based on Hansen (1999), the empirical result shows that dual cost capacity utilization of manufacturing industries are generally below the level of NAICU, which is $80 \%$.
\end{abstract}

Keyword: Capacity utilization, inflation, threshold regression, panel.

JEL Classification: D24, E31, C12, C33.

1 Kelompok Riset Ekonomi, Biro Riset Ekonomi, Direktorat Riset Ekonomi dan Kebijakan Moneter, Bank Indonesia. E-mail: endydt@bi.go.id; jardine@bi.go.id; desthy@bi.go.id. Kami berterimakasih kepada Dr. Perry Warjiyo untuk masukannya yang berharga. Kami juga berterimkasih kepada masukan maupun bantuan data dari staff di DKM-Bank Indonesia. Pandangan dalam paper ini merupakan pandangan penulis dan tidak merupakan pandangan Bank Indonesia. 


\section{PENDAHULUAN}

Pentingnya penelitian mengenai tingkat penggunaan kapasitas terpasang bagi bank sentral tentunya tidak perlu dipertanyakan lagi, karena tingkat penggunaan kapasitas terpasang ini menjadi salah satu indikator terpenting dalam perumusan kebijakan moneter. Tingkat penggunaan kapasitas terpasang yang masih rendah mengindikasikan perlunya kebijakan moneter yang ekspansif, sebaliknya tingkat penggunaan kapasitas terpasang yang tinggi mengindikasikan perlunya kebijakan moneter ketat untuk mencegah menguatnya tekanan inflasi.

Namun demikian, penelitian ini dirasakan masih belum lengkap karena belum ada penelitian yang bisa mengatakan dengan pasti tingkat penggunaan kapasitas terpasang pada level berapa yang belum memberikan tekanan inflasi dan pada level berapa yang sudah memberikan tekanan inflasi. Dalam literatur, batasan ini dikenal dengan NAICU, singkatan dari Non-Accellerating Inflation rate of Capacity Utilization. Menurut konsep ini, NAICU merupakan batas atas dimana output gap belum memberikan tekanan pada inflasi. Hal ini berarti bahwa upaya mendorong pertumbuhan output dapat dilakukan tanpa menimbulkan tekanan inflasi sepanjang output gap masih berada dibawah NAICU. Pada saat output sudah mencapai NAICU maka setiap kenaikan output gap berarti akan meningkatkan tekanan inflasi.

Menyadari pentingnya penelitian mengenai NAICU ini, maka untuk mengukur NAICU dalam paper ini digunakan pendekatan 'metode threshold' yang dikembangkan oleh Hansen (1999). Untuk menjaga kesinambungan dari hasil riset sebelumnyªa, paper ini menggunakan data hasil pengukuran tingkat penggunaan kapasitas terpasang dengan metode dual cost.

Pembahasan dalam paper ini akan diawali dengan studi literatur menyangkut model phillip curve dan konsep NAICU yang akan digunakan, diikuti oleh metodologi dan data, bagian selanjutnya menyajikan analisa hasil empiris, dan bagian terakhir ialah kesimpulan dan rekomendasi kebijakan.

\section{TEORI}

\section{II.1. Kerangka Dasar Phillips Curve}

Istilah Kurva Philips muncul pada tahun 1958 ketika Phillips meneliti hubungan data empiris upah dan inflasi di Inggris. Dia mengamati adanya hubungan yang berlawanan arah antara pengangguran dengan laju inflasi. Pada saat Orotitas menggunakan kebijakan moneter/ 
fiskal ekapansif maka ekonomi akan bergeser sepanjang kurva penawaran jangka pendek menuju output dan inflasi yang lebih tinggi. Kenaikan output ini berarti menaikkan kesempatan kerja, yang berarti menurunkan pengangguran. Jadi, kenaikan inflasi diiukuti penurunan pengangguran, dan sebaliknya turunnya inflasi diikuti oleh kenaikan pengangguran.

Dalam perkembangannya, istilah Kurva Phillips ini menjadi istilah umum yang menggambarkan hubungan antara perubahan harga nominal/upah nominal dengan tingkat intensitas suatu permintaan, seperti tingkat pengangguran. Saat ini, Kurva Phllips menyatakan bahwa laju inflasi ditentukan oleh 3 faktor yaitu (i) ekspektasi inflasi, (ii) deviasi tingkat pengangguran dari natural rate of unemployment atau dikenal dengan istilah tingkat pengangguran siklikal, dan (iii) supply shocks. Secara matematis dinyatakan dengan:

$$
\pi=\pi^{e}-\beta\left(u-u^{n}\right)+v
$$

dimana

$$
\begin{aligned}
\pi= & \text { tingkat inflasi } \\
\pi^{e}= & \text { ekspektasi inflasi } \\
\beta= & \text { merupakan parameter yang menyatakan besarnya respons inflasi terhadap tingkat } \\
& \text { pengangguran siklikal. } \\
v= & \text { supply shock }
\end{aligned}
$$

Persamaan Kurva Phllips ini sebenarnya diturunkan dari kurva penawaran agregat jangka pendek $^{3}$ dan keduanya menjelaskan ide yang sama namun dengan penekanan yang berbeda. Kurva penawaran angregat jangka pendek lebih menekankan hubungan antara output dengan perubahan harga yang tidak diperkirakan, sedangkan Kurva Phillips menjelaskan tingkat pengangguran dengan perubahan harga yang tidak diperkirakan.

Untuk menentukan ekspektasi inflasi, salah satu pendekatan yang sering dipakai adalah menggunakan asumsi adaptive expectations. Menurut pendekatan ini, masyarakat memperkirakan tingkat inflasi ke depan tidak akan jauh berbeda dengan laju inflasi periode sebelumnya, atau $\pi^{e}=\pi_{t-1}$ sehingga persamaan Kurva Phillips dapat dinyatakan dengan :

$$
\pi=\pi_{t-1}-\beta\left(u-u^{n}\right)+v
$$

Persamaan d iatas mengindikasikan bahwa inflasi memiliki inersia. Hal ini disebabkan inflasi di masa lalu mempengaruhi ekspektasi di masa depan dan karena itu mempengaruhi penetapan harga-harga dan upah. Dalam bentuk kurva penawaran agregat dan permintaan

3 Penurunan rumusnya dapat dilihat pada Mankiw (2002). 
agregat, inersia dari inflasi ini tercermin pada persistensi kurva penawaran ataupun permintaan untuk bergeser keatas.

Tingkat pengangguran siklikal, yang diukur dari deviasi tingkat pengangguran terhadap tingkat pengangguran jangka panjang (tingkat pengangguran natural) bisa memberikan tekanan inflasi ke atas atau ke bawah. Tingkat pengangguran yang lebih rendah akan mendorong kenaikan inflasi, atau yang dikenal dengan demand-pull inflation. Parameter $\beta$ mengukur seberapa kuat respons inflasi terhadap perubahan tingkat pengangguran siklikal.

Sementara, supply shocks mencerminkan cost-push inflation. Kenaikan supply shock, seperti kenaikan harga minyak, menyebabkan nilai v positif yang berarti memberikan kontribusi terhadap kenaikan inflasi. Beberapa faktor yang termasuk supply shocks diantaranya adalah panen raya, gangguan distribusi, pemogokan buruh yang menghambat proses produksi, dll.

\section{II.2. Konsep NAIRU dan NAICU}

NAIRU merupakan singkatan dari Non-Accelerated Inflation Rate of Unemployment, yang artinya tingkat pengangguran yang tidak mendorong pada percepatan laju inflasi. Menurut konsep ini, NAIRU merupakan batas atas dimana tingkat pengangguran belum memberikan tekanan pada laju inflasi. Pada saat tingkat pengangguran sama dengan NAIRU kurva Phillips berbentuk vertikal. Hal ini mengimplikasikan bahwa upaya penurunan inflasi hanya dapat dilakukan bila tingkat pengangguran aktual lebih tinggi dari NAIRU. Dalam hal tingkat pengangguran sudah mencapai NAIRU maka penurunan tingkat pengangguran akan mendorong pada laju inflasi.

Konsep mengenai NAIRU agak berbeda dengan natural rate of unemployment. Natural rate of unemployment biasanya merujuk pada tingkat pengangguran dalam kondisi keseimbangan. Dalam hal ini, dalam kondisi keseimbangan, diyakini ada satu tingkat pengangguran tertentu pada tingkat output dan inflasi yang tertentu. Sementara, NAIRU merujuk pada hubungan antara ekses permintaan/penawaran tenaga kerja dengan laju inflasi sebagaimana digambarkan dalam Kurva Phillips.

Sejalan dengan Okun's Law yang mengkaitkan antara output gap dengan labor market gap, maka konsep yang sama juga banyak dipakai untuk NAICU, singkatan dari Non-Accelerating Inflation rate of Capacity Utilization. Menurut konsep ini, NAICU merupakan batas atas dimana output gap belum memberikan tekanan pada inflasi. Hal ini berrati bahwa upaya mendorong pertumbuhan output dapat dilakukan tanpa menimbulkan tekanan inflasi sepanjang output gap masih berada dibawah NAICU. Pada saat output sudah mencapai NAICU maka setiap kenaikan output gap berarti akan meningkatkan tekanan inflasi. 


\section{II.3. Triangle Model of Inflation}

Model inflasi segitiga pertama kali diperkenalkan oleh Gordon (1977) dan hingga kini banyak dipakai oleh para ekonom untuk menyusun model inflasi. Menurut model ini, inflasi dipengaruhi oleh 3 faktor, yaitu inersia, permintaan, dan penawaran. Secara umum, model ini dinyatakan dengan persamaan :

$$
\pi_{t}=a(L) \pi_{t-1}+b(L) D_{t}+c(L) z_{t}+\varepsilon_{t}
$$

dimana,

$$
\begin{aligned}
& \pi=\text { laju inflasi } \\
& \mathrm{D}=\text { indeks yang menggambarkan excess demand } \\
& \mathrm{Z}=\text { vektor yang mewakili variabel supply shocks } \\
& e \quad=\text { error }
\end{aligned}
$$

Inersia menggambarkan kecenderungan inflasi untuk menyimpang secara perlahan dari angka inflasi pada periode sebelumnya. Ketika ekonomi mendapatkan tekanan dari supply shocks, inflasi memberikan respons secara perlahan. Adanya inersia inflasi ini disebabkan oleh perkembangan ekspektasi yang sulit untuk berubah. Faktor lain yang juga turut membentuk inersia adalah adanya kontrak jangka panjang dalam pembentukan harga dan upah. Studi empiris membuktikan efek inersia ini berjalan dari satu kuartal hingga beberapa kuartal ke depan, sehingga banyak dipakai pada model empiris dengan data kuartalan.

Apabila jumlah koefisien dari variabel lag berjumlah satu maka pengaruh variabel demand menggambarkan secara tepat kondisi natural rate yang konsisten dengan laju inflasi yang konstan. Bila perlu, koefisien lag variabel ini dikonstrain dengan satu.

Ekses demand dalam persamaan diatas menggambarkan kondisi permintaan agregat terhadap penawaran agregat. Penawaran agregat cenderung untuk terus naik sejalan dengan kenaikan jumlah tenaga kerja, kapital, dan penguasaan teknologi. Dalam jangka panjang, output diyakini tumbuh secara konstan. Kondisi ekonomi dikatakan terjadi ekses demand jika permintaan agregat tumbuh melebihi penawaran agregat. Hal ini akan mendorong pada kenaikan inflasi. Sebaliknya, bila permintaan agregat tumbuh dibawah pertumbuhan penawaran agregat maka pertumbuhan ekonomi akan melambat yang segera diikuti oleh penurunan inflasi.

Beberapa variabel yang bisa digunakan sebagai proksi dari ekses demand diantaranya adalah output gap, yaitu rasio antara aktual dengan potensial output riil. Selain itu, bisa juga digunakan unemployment gap, yaitu selisih antara tingkat pengangguran aktual dengan tingkat naturalnya. Alternatif lain adalah tingkat penggunaan kapasitas terpasang (capacity utilization). 
Supply shocks termasuk salah satu determinan inflasi berdasarkan pertimbangan atas pengaruhnya terhadap kenaikan biaya produksi. Pada awalnya, Kurva Phillips yang banyak dikembangkan pada era 1970-an belum memasukkan supply shocks sebagai determinan inflasi. Namun, sejalan dengan terjadinya krisis harga minyak di tahun 1970-an dan 1980-an yang menyebabkan kenaikan biaya produksi dan mendorong laju inflasi dunia, maka supply shocks semakin diyakini perlu masuk sebagai salah satu determinan inflasi. Apabila tanpa memasukkan faktor supply shocks maka akan terjadi permasalahan mis-spesifikasi model (omitted variable). Beberapa variabel yang potensial untuk digunakan sebagai proksi bagi supply shocks ini diantaranya adalah harga impor, harga makanan, dan harga energi.

Sebenarnya masih ada 2 faktor determinan inflasi yang tidak masuk dalam persamaan model segitiga yaitu perubahan upah dan kurs. Perubahan upah mempengaruhi inflasi melalui perubahan biaya produksi. Akibatnya, perubahan biaya produksi ini akan dikompensasi dengan perubahan harga. Dengan demikian, pengaruh perubahan upah ini bisa ditangkap di salah satu variabel supply shocks. Sementara itu, beberapa peneliti masih mempertanyakan perlunya perubahan upah masuk sebagai salah satu determinan inflasi karena data upah dan inflasi, khususnya untuk data kuartalan, umumnya bergerak tidak searah. Disamping itu, dalam prakteknya, perubahan upah tidak selalu ditransmisikan pengusaha pada kenaikan harga jual karena dalam banyak kasus kenaikan upah ini diserap perusahaan dengan menurunkan margin keuntungan.

Sementara itu, kurs mempengaruhi inflasi melalui perubahan harga bahan baku impor. Dalam hal ini perlu diperhatikan apakah perubahan kurs ini akan ditransmisikan ke perubahan harga bahan baku impor secara penuh atau hanya sebagian. Hal ini tergantung pada exchange rate passthrough. Namun demikian, bila persamaan sudah memasukkan harga bahan baku impor sebagai salah satu determinan inflasi maka sebaiknya kurs tidak perlu lagi digunakan sebagai variabel independen untuk mencegah terjadinya multi-collinearity antara kurs dengan harga bahan baku impor. Demikian pula sebaliknya.

\section{METODOLOGI}

Sesuai dengan tujuan penelitian, studi ini akan mengestimasi nilai ambang batas (threshold) capacity utilization ${ }^{4}$ atau NAICU (non-accelerating inflation rate of capacity utilization) untuk sektor industri pengolahan Indonesia. Terdapat tiga pengertian mengenai nilai threshold, yaitu (i) dari sisi definisi umum (the World Book Dictionary, 1994):

\footnotetext{
4 Estimasi threshold telah dilakukan antara lain oleh studi Sarel (1996), Rousseau dan Wachtel (2002), Laksono (2004). Metode ekonometrika pencarian nilai threshold disempurnakan oleh Hansen (1999, 2000).
} 
"Threshold is a point at which two stimulus can be differentiated."

(ii) dari sisi ekonometrika, nilai threshold merupakan suatu nilai "target" yang besarnya tidak selalu diketahui dengan jelas (Gujarati, 2003: 318), dan (iii) dari sisi ekonomi, khususnya dalam konteks inflasi, menurut Dotsey dan Stark (2005) meskipun pada awalnya teori dasar diformulasikan berdasarkan hubungan antara tingkat harga dengan capacity utilization, teori modern menghubungkan inflasi dengan capacity utilization:

"This theory suggests that prices increase at a faster rate when utilization rates are high".

Berdasarkan definisi-definisi diatas, nilai threshold adalah suatu titik di mana dua stimulus dapat dibedakan dan nilai tersebut tidak diketahui secara jelas. Oleh karena itu, nilai threshold tersebut harus diestimasi. Dalam konteks studi ini, tingkat capacity utilization dianggap mempunyai dua stimulus yang berbeda - tingkat capacity utilization di bawah tingkat NAICU dianggap tidak akan mempercepat laju inflasi, sedangkan tingkat capacity utilization di atas tingkat NAICU akan mempercepat laju inflasi. Berdasarkan pertimbangan itulah perumusan kebijakan moneter harus memperhatikan tingkat capacity utilization di perekonomian agar dapat meminimasi inflationary consequences dari kebijakan moneter.

Penelitian ini akan merujuk pada metode estimasi threshold oleh Hansen (1999) untuk model non-dynamic panel data yang akan dijelaskan pada bab ini.

\section{III.1. Kerangka Model dan Pengujiannya}

\section{III.1.1. Threshold Regression Models untuk Data Panel}

Bila $y_{i t}$ menyatakan dependent variable untuk individu $i$ dan waktu $t$ sedangkan $x_{j i t}$ adalah independent variable dengan $i=1,2, \ldots, n, t=1,2, \ldots, T, j=1,2, \ldots, k$ maka threshold regression model untuk data panel dengan fixed effect untuk dua buah regime dapat dinyatakan melalui persamaan:

$$
\begin{aligned}
& y_{i t}=\mu_{i}+\left(\alpha_{1} x_{1 i t}+\alpha_{2} x_{2 i t}+\ldots+\alpha_{k} x_{k i t}\right) I_{\left(q_{i t} \leq \gamma\right)} \\
& +\left(\beta_{1} x_{1 i t}+\beta_{2} x_{2 i t}+\ldots+\beta_{k} x_{k i t}\right) I_{\left(q_{i t}>\gamma\right)}+e_{i t}
\end{aligned}
$$

dengan $I_{\left(q_{i i} \leq \gamma\right)}$ menyatakan fungsi indikator yang bernilai 1 bila $q_{i t} \leq \gamma$ dan bernilai 0 bila $q_{i t}>\gamma$.

$$
I_{\left(q_{i t} \leq \gamma\right)}=\left\{\begin{array}{l}
1 \text { bila } q_{i t} \leq \gamma \\
0 \text { bila } q_{i t}>\gamma
\end{array}\right.
$$

dan

$$
I_{\left(q_{i t}>\gamma\right)}=\left\{\begin{array}{l}
1 \text { bila } q_{i t}>\gamma \\
0 \text { bila } q_{i t} \leq \gamma
\end{array}\right.
$$


sedangkan $q_{i t}$ adalah threshold variable yang berupa skalar dan $\gamma$ adalah threshold parameter. Parameter $\mu_{i}$ menyatakan individual effect. Parameter $\alpha_{j}$ untuk $j=0,1,2 \ldots k$ adalah koefisien bila $q_{i t}<\gamma$ sedangkan parameter $\beta_{j}$ untuk $j=0,1,2 \ldots k$ adalah koefisien bila $q_{i t}>\gamma$. Diasumsikan $e_{i t} \sim$ i.i.d. $N\left(0, \sigma^{2}\right)$.

Pada model (V.4), sampel dipisah menjadi dua bagian. Bagian pertama, disebut regime pertama, berisi sampel yang memenuhi kriteria $q_{i t} \leq \gamma$ dan bagian kedua, disebut regime kedua, berisi sampel yang memenuhi kriteria $q_{i t}>\gamma$. Pada regime pertama digunakan model dengan parameter $\alpha$ sedangkan pada regime kedua digunakan model dengan parameter $\beta$. Bila $\alpha \neq \beta$ maka threshold regression model (V.4) memang layak untuk dipakai. Namun bila $\alpha=\beta$ maka model regresi biasa yang layak dipakai. Karena itu perlu diuji hipotesa bahwa $\alpha=\beta$. Hasil dari pengujian hipotesa ini akan menentukan apakah threshold regression model (V.4) yang akan kita gunakan, ataukah model regresi yang biasa.

Besarnya nilai $\gamma$ tidak diketahui, karenanya harus ditaksir. Parameter $\gamma$ inilah yang akan menentukan cara sampel dipisahkan. Bila $I_{\left(q_{i} \leq \gamma\right)}$ atau $I_{\left(q_{i}>\gamma\right)}$ untuk seluruh sampel maka keadaan ini serupa dengan keadaan $\alpha=\beta$.

Sebagai penyederhanaan notasi, dapat dituliskan:

$$
\begin{aligned}
& x_{i t}^{\prime}=\left(\begin{array}{llll}
x_{1 i t} & x_{2 i t} & \mathrm{~K} & x_{k i t}
\end{array}\right), \\
& x_{i t}(\gamma)=\left(\begin{array}{lll}
x_{i t}^{\prime} I_{\left(q_{i t} \leq \gamma\right)} & \mathrm{M} & x_{i t}^{\prime} I_{\left(q_{i t}>\gamma\right)}
\end{array}\right) \\
& \alpha=\left(\begin{array}{c}
\alpha_{I} \\
\mathrm{M} \\
\alpha_{k}
\end{array}\right) \text { dan } \beta=\left(\begin{array}{c}
\beta_{1} \\
\mathrm{M} \\
\beta_{k}
\end{array}\right)
\end{aligned}
$$

Dimensi dari $x_{i t}$ adalah $k \mathrm{x}$ i dan dimensi dari $x_{i}(\gamma)$ adalah $2 k \mathrm{x} 1$. Dengan notasi vektor, persamaan (V.4) dapat dinyatakan dengan

$$
y_{i t}=\mu_{i}+x_{i t}^{\prime \alpha} \alpha I_{(q i t \leq \gamma)}+x_{i t}^{\prime} \beta I_{(q i t>\gamma)}+e_{i t}
$$

atau

$$
y_{i t}=\mu_{i}+x_{i t}(\gamma)^{\prime} \theta+e_{i t}
$$

dengan

$$
\theta=\left(\begin{array}{c}
\alpha \\
\Lambda \\
\beta
\end{array}\right)_{2 k x 1}
$$

Parameter $\theta$ tidak bisa langsung ditaksir karena nilai $\gamma$ belum diketahui. Karena itu, akan diberikan suatu nilai $\gamma$, untuk kemudian akan dilakukan penaksiran $\theta$ dengan mula-mula menghilangkan parameter fixed effect $\mu_{i}$ melalui cara berikut: 
Pada persamaan (V.11) diambil nilai rata-rata terhadap waktu dan didapat

$$
\bar{y}_{i}=\mu_{i}+\bar{x}_{i}(\gamma) \theta+\overline{e_{i}}
$$

dengan

$$
\bar{y}_{i}=\frac{1}{T} \sum_{t=1}^{T} y_{i t}, \bar{x}_{i}(\gamma)=\frac{1}{T} \sum_{t=1}^{T} \bar{x}_{i t}(\gamma), \overline{e_{i}}=\frac{1}{T} \sum_{t=1}^{T} e_{i t}
$$

Selisih antara (V.11) dan (V.13) adalah

$$
y_{i t}-\bar{y}_{i}=\left[x_{i t}(\gamma)^{\prime}-\bar{x}_{i}(\gamma)^{\prime}\right] \theta+\left[e_{i t}-\bar{e}_{i}\right]
$$

yang diringkas penulisannya menjadi

$$
y_{i t}^{*}=x_{i t}^{*}(\gamma)^{\prime} \theta+e_{i t}^{*}
$$

dengan

$$
\begin{aligned}
& y_{i t}^{*}=y_{i t}-\bar{y}_{i} \\
& x_{i t}^{*}(\gamma)^{\prime}=x_{i t}(\gamma)^{\prime}-\bar{x}_{i}(\gamma)^{\prime} \\
& e_{i t}^{*}=e_{i t}-\bar{e}_{i} \\
& i=1,2, \ldots, n
\end{aligned}
$$

Bila dinyatakan dalam notasi vektor, variabel-variabel ini menjadi

$$
\begin{aligned}
& y_{i}^{*}=\left(\begin{array}{c}
y_{i 2}^{*} \\
y_{i 3}^{*} \\
\mathrm{M} \\
y_{i T}^{*}
\end{array}\right)_{(T-1) \times 1}, x_{i}^{*}(\gamma)^{\prime}=\left(\begin{array}{c}
x_{i 2}^{*}(\gamma)^{\prime} \\
x_{i 3}^{*}(\gamma)^{\prime} \\
\mathrm{M} \\
x_{i T}^{*}(\gamma)^{\prime}
\end{array}\right)_{(T-1) x k}, e_{i}^{*}=\left(\begin{array}{c}
e_{i 2}^{*} \\
e_{i 3}^{*} \\
\mathrm{M} \\
e_{i T}^{*}
\end{array}\right)_{(T-1) \times 1} \\
& i=1,2, \ldots, n
\end{aligned}
$$

Bila variabel-variabel ini di-stacked untuk seluruh individu maka akan diperoleh

$$
Y^{*}=\left(\begin{array}{c}
y_{i}^{*} \\
y_{2}^{*} \\
\mathrm{M} \\
y_{n}^{*}
\end{array}\right)_{\mathrm{n}(T-1) \mathrm{x} 1}, X^{*}=\left(\begin{array}{c}
x_{i}^{*}(\gamma) \\
x_{2}^{*}(\gamma) \\
\mathrm{M} \\
x_{n}^{*}(\gamma)^{\prime}
\end{array}\right)_{\mathrm{n}(T-1) x k}, e^{*}=\left(\begin{array}{c}
e_{1}^{*} \\
e_{2}^{*} \\
\mathrm{M} \\
e_{n}^{*}
\end{array}\right)_{\mathrm{n}(T-1) \times 1}
$$

sehingga model (V.16) dapat dinyatakan dengan

$$
Y^{*}=X^{*}(\gamma) \theta+e^{*}
$$

Untuk nilai $\gamma$ yang telah diberikan, penaksir $\theta$ dengan least square atau minimum likelihood akan memberikan hasil yang sama 


$$
\hat{\theta}(\gamma)=\left(X^{*}(\gamma)^{\prime} X^{*}(\gamma)\right)^{-1} X^{*}(\gamma)^{\prime} Y^{*}
$$

dengan residu dan the sum of squared error-nya adalah

$$
\begin{aligned}
& \hat{e}^{*}(\gamma)=Y^{*}-X^{*}(\gamma) \hat{\theta}(\gamma) \\
& S_{1}(\gamma)=\hat{e}^{*}(\gamma)^{\prime} \hat{e}^{*}(\gamma)
\end{aligned}
$$

sedangkan penaksir maximum likelihood untuk $\sigma^{2}$ adalah

$$
\hat{\sigma}^{2}(\gamma)=\frac{\hat{e}^{*}(\gamma)^{\prime} \hat{e}^{*}(\gamma)}{n(T-1)}
$$

Untuk berbagai nilai $\gamma$ yang mungkin maka taksiran untuk $\theta$ dan $\sigma^{2}$ dapat diperoleh melalui (V.24) dan (V.27), sedangkan sendiri dapat ditaksir melalui pilihan yang akan meminimumkan (V.26):

$$
\hat{\gamma}=\underset{\gamma \in \Gamma}{\arg \min } S_{1}(\gamma)
$$

dengan

$$
\Gamma=(\underline{\gamma}, \bar{\gamma})
$$

Nilai-nilai $\hat{\sigma}^{2}(\gamma)$ di persamaan (V.27) nilainya akan tergantung pada $\gamma$ yang ragam nilainya paling banyak $n T$ buah. Karena itu, penaksiran $\gamma$ dilakukan dengan menghitung (V.27) untuk berbagai nilai $\gamma \in \Gamma$ dan dipilih sebagai taksiran $\hat{\gamma}$ yang memenuhi (V.28). Penentuan $\underline{\gamma}$ dan $\bar{\gamma}$ dilakukan dengan pertimbangan bahwa sample di salah satu regime tidak boleh terlalu sedikit. Bila $\hat{\gamma}$ sudah diperoleh maka penaksir $\theta$ adalah modifikasi dari (V.24)

$$
\hat{\theta}=\hat{\theta}(\hat{\gamma})
$$

demikian pula taksiran penaksir untuk $\sigma^{2}$ adalah modifikasi dari (V.27)

$$
\hat{\sigma}^{2}=\hat{\sigma}^{2}(\hat{\gamma})
$$

dengan residunya adalah modifikasi dari (V.22)

$$
\hat{e}^{*}(\hat{\gamma})=Y^{*}-X^{*}(\hat{\gamma}) \hat{\theta}(\hat{\gamma})
$$

\section{III.1.2. Pengujian Hipotesa}

Setelah mentaksir parameter, perlu dibuktikan apakah pengaruh threshold tersebut cukup signifikan. Hipotesa yang akan diuji adalah

$$
\begin{aligned}
& H_{0}: \alpha=\beta \\
& H_{1}: \alpha \neq \beta
\end{aligned}
$$


Di bawah $H_{o}$ parameter $\gamma$ tidak teridentifikasi nilainya karena tidak ada pengaruh threshold sehingga likelihood ratio test-nya mempunyai distribusi yang tidak baku. Oleh karena itu penentuan nilai kritis dari test tersebut akan dilakukan dengan prosedur bootstrap.

Di bawah $H_{o}$ pengaruh threshold tidak ada sehingga model (V.11) dapat dinyatakan dengan

$$
y_{i t}=\mu_{i}+x_{i t}^{\prime} \alpha+e_{i t}
$$

dan model (V.16) menjadi

$$
y_{i t}^{*}=x_{i t}^{*^{\prime}} \alpha+e_{i t}^{*}
$$

yang bisa dituliskan dalam notasi matriks

$$
Y^{*}=X^{*} \alpha+e^{*}
$$

dengan $X$ adalah matriks dari (V.7)

$$
X^{*}=\left(\begin{array}{c}
x_{1}^{\prime} \\
x_{2}^{\prime} \\
\mathrm{M} \\
x_{T}^{\prime}
\end{array}\right)
$$

Parameter $\alpha$ di (V.36) dapat ditaksir dengan LS

$$
\hat{\alpha}=\left(X^{*^{\prime}} X^{*}\right)^{-1} X^{*^{\prime}} Y^{*}
$$

sehingga diperoleh residu

$$
\widetilde{e}^{*}=Y^{*}-X^{*} \hat{\alpha}
$$

dengan sum of squared errors-nya

$$
S_{0}=\widetilde{e}^{*^{\prime}} \widetilde{e}^{*}
$$

Statistik uji untuk hipotesa (V.33) dapat dinyatakan oleh

$$
F=\left(\frac{S_{0}-S_{1}(\hat{\gamma})}{\hat{\sigma}^{2}(\hat{\gamma})}\right)
$$

Distribusi asimptotik dari $F$ tidaklah baku, sehingga nilai kritisnya tidak diketahui. Penentuan nilai kritis dari test $F$ akan dilakukan aproksimasi dari distribusi asimptotik $F$ melalui prosedur bootstrap. 


\section{III.1. 3. Prosedur Bootstrap}

Untuk menentukan nilai kritis dari test $F$, dilakukan aproksimasi distribusi asimptotik $F$ melalui prosedur bootstrap sebagai berikut:

1. Dari residual (V.32) aturlah penulisannya sehingga residual untuk seluruh individu dapat dikoleksikan menjadi

$\left\{\hat{e}_{1}^{*}(\hat{\gamma}), \hat{e}_{2}^{*}(\hat{\gamma}), \mathrm{L}, \hat{e}_{n}^{*}(\hat{\gamma})\right\}$

dengan $\hat{e}^{*}(\hat{\gamma})$ berupa vector baris residu untuk individu $i=1,2, \ldots, n$

$\hat{e}_{i}^{*}(\hat{\gamma})=\left(\hat{e}_{i 1}^{*}(\hat{\gamma}), \hat{e}_{i 2}^{*}(\hat{\gamma}), \mathrm{L}, \hat{e}_{i T}^{*}(\hat{\gamma})\right)$

2. Dari koleksi (V.42) kita ambil sample acak residu dengan pengembalian sebesar $n$.

3. Hasil sample di langka 2 dipergunakan untuk menciptakan $y_{i t}^{*}$ dari (V.16) dengan parameter $\alpha$ boleh diganti dengan $\hat{\alpha}$.

4. $y_{i t}^{*} \quad$ yang dihasilkan oleh langkah 3 akan dipergunakan untuk menaksir $\alpha$ di (V.16) yang nantinya akan digunakan untuk menghitung $\mathrm{S}_{1}(\hat{\gamma})$ dan (35) yang kelak akan digunakan untuk menghitung $S_{o}$.

5. Dari hasil perhitungan $S_{o}$ dan $\mathrm{S}_{1}(\hat{\gamma})$ di langkah 4, kita hitung $F^{*}$ seperti di (V.41)

$$
F^{*}=\left(\frac{S_{0}-S_{1}(\hat{\gamma})}{\hat{\sigma}^{2}(\hat{\gamma})}\right)
$$

6. Ulangi langkah 1-5 berkali-kali (misalnya 10000 kali)

7. Perhitungan $p$-value untuk $F$ dari (V.41) didapat dari proporsi $F^{*}$ yang lebih besar dari $F$

8. Tolak hipotesa (33) bila $p$-value dari langkah 5 lebih kecil dari level of significance (misalnya 0.05 atau 0.1$)$

\section{III.2. Model Empiris}

Model empiris yang akan diestimasi dalam penelitian ini berangkat dari triangle model (lihat Bab II Landasan Teori) sebagai model dasarnya. Namun demikian model empiris yang diestimasi tidak memasukkan faktor inersia ke dalam persamaan berdasarkan beberapa pertimbangan, yaitu (i) beberapa studi pembentukan inflasi Indonesia sebelumnya (menggunakan model kwartalan) memperlihatkan bahwa faktor inersia dengan lag terjauh yang masih signifikan mempengaruhi inflasi periode saat ini merupakan inflasi dua kwartal sebelumnya ${ }^{5}$, sehingga besar kemungkinan bahwa inflasi satu tahun sebelumnya tidak akan memiliki pengaruh yang signifikan, (ii) model yang diestimasi memiliki struktur data panel, sehingga faktor inersia

5 Lihat Darsono, Majardi dan Hartwan (2002) untuk model SSMX dan Quarterly Macroeconomic Model, Bank Indonesia (2003) untuk model SOFIE 
membutuhkan digunakannya model dynamic panel data yang akan menyebabkan transformasi bentuk model yang tidak sesuai dengan model teoritis penentuan NAICU. ${ }^{6}$

Model empiris tersebut ialah sebagai berikut:

$$
\begin{aligned}
& \Delta \pi_{i t}=\alpha_{i}+\gamma C U_{i t-1}+\sum \beta_{1 k} \Delta s_{i t-k}+\sum \beta_{2 k} \Delta \text { wage }_{i t-k}+\varepsilon_{i t} \\
& \Delta \pi_{i t}=\alpha_{i}+\gamma_{1}\left(C U_{i t-1}<C U^{*}\right)+\gamma_{2}\left(C U_{i t-1} \geq C U^{*}\right)+\sum \beta_{3 k} \Delta s_{i t-k}+\sum \beta_{4 k} \Delta \text { wage }_{i t-k}+\varepsilon_{i t}
\end{aligned}
$$

dimana $\Delta \pi$ merupakan inflasi core yoy yang sudah mengeluarkan faktor administered price dan volatile food, $C U$ merupakan dual cost capacity utilization, $\Delta$ s merupakan perubahan nilai tukar nominal rupiah rata-rata tahunan (depresiasi atau apresiasi), dan $\Delta$ wage merupakan pertumbuhan tahunan rata-rata upah nominal sektor industri pengolahan. Persamaan (V.45) merupakan persamaan tanpa threshold dan persamaan (V.46) merupakan persamaan dengan threshold pada variabel $C U$. Variabel $C U^{*}$ merupakan tingkat NAICU yang akan dicari. Persamaan (V.46) diestimasi berulang kali dimulai dari $C U^{*}=65$ sampai dengan $C U^{*}=90$ untuk mendapatkan threshold optimum dengan nilai sum of squared residual yang terkecil. Untuk menguji efek threshold dilakukan prosedur bootstrap seperti yang telah dijelaskan pada bagian sebelumnya, dengan 1000 kali pengulangan.

Model panel data tersebut terdiri dari 9 cross-section yang merupakan keseluruhan subsektor dari sektor industri pengolahan. Kesembilan subsektor itu ialah (i) alat angkutan, mesin dan peralatannya, (ii) barang dari kayu, rotan dan rumput-rumputan, (iii) kertas, percetakan dan penerbitan, (iv) bahan kimia, karet dan plastik, (v) logam dasar, (vi) makanan, minuman dan tembakau, (vii) barang galian bukan logam, (viii) tekstil, pakaian jadi dan kulit, dan (ix) industri pengolahan lainnya.

Variabel yang mewakili faktor supply shock pada model ini ialah variabel nilai tukar dan variabel upah. Seperti yang telah dijelaskan pada bab sebelumnya, faktor supply shock merupakan faktor cost push yang dapat mempengaruhi inflasi seperti antara lain harga bahan makanan pokok, peraturan harga pemerintah, harga impor maupun upah nominal. Untuk itu, agar dapat memperoleh hasil yang lebih akurat, inflasi yang digunakan dalam model estimasi ialah inflasi yang sudah mengeluarkan beberapa faktor supply shock itu sendiri yaitu faktor peraturan harga pemerintah dan faktor harga bahan makanan pokok.

\footnotetext{
6 Model dynamic panel data pada umumnya membutuhkan akan mentransformasi bentuk model awal untuk menghilangkan period fixed factor dari model awal. Salah satu model dynamic panel data yang sering digunakan misalnya model GMM oleh Arellano dan Bond (1991) akan mentransformasi model awal menjadi bentuk first difference dan model GMM oleh Arellano dan Bond (1995) dengan transformasi orthogonal deviation. Hal ini tidak sesuai dengan Phillip curve triangle model dimana variabel capacity utilization masuk dalam bentuk level. Untuk lebih jelasnya baca Baltagi (2001).
} 
Variabel nilai tukar dalam model ini selain dapat berfungsi sebagai proksi dari harga impor juga dapat berfungsi sebagai faktor yang dapat mempengaruhi ekspektasi. Hal ini juga sudah dilkukan oleh beberapa studi pembentukan inflasi seperti misalnya pada Darsono, Majardi dan Hartawan (2003).

Model empiris pada persamaan (V.45) diestimasi dengan menggunakan model fixed effect panel data dengan teknik estimasi general to parsimonious dengan memasukkan lag yang diduga dapat memiliki pengaruh yang signifikan. Dalam hal ini dengan pertimbangan penggunaan periode tahunan, lag yang dimasukkan hanya sampai dengan satu periode sebelumnya. Setelah itu, persamaan (V.46) diestimasi dengan manggunakan variabel yang sama dengan persamaan (V.45). Pengunaan metode fixed effect dilakukan berdasarkan pertimbangan bahwa data cross-section sudah mewakili keseluruhan populasi sektor industri pengolahan. Namun demikian uji Hausmantest, untuk melihat ketepatan pemilihan model fixed effect dibadingkan dengan model random effect, dan uji fixed effect-test, untuk melihat apakah model dengan cross-section fixed effect merupakan model yang tepat, keduanya akan tetap dilakukan.

\section{III.3. Data}

Data yang digunakan ialah data tahunan dari 9 sub sektor industri pengolahan. Untuk variabel inflasi, data yang digunakan merupakan inflasi core dari masing-masing subsektor, yaitu inflasi IHK yang telah mengeluarkan komponen administered price dan volatile food. Untuk variabel capacity utilization, data yang digunakan merupakan data hasil studi Tjahjono, Husman dan Sianipar (2005), yang merupakan data capacity utilization per sub sektor berdasarkan metode dual cost (economic approach). Untuk variabel nilai tukar dan upah nominal, data yang digunakan merupakan rata-rata tahunan untuk keseluruhan industri pengolahan. Plot dari stacked data keempat variabel tersebut dapat dilihat pada Grafik V.1 - V.4.
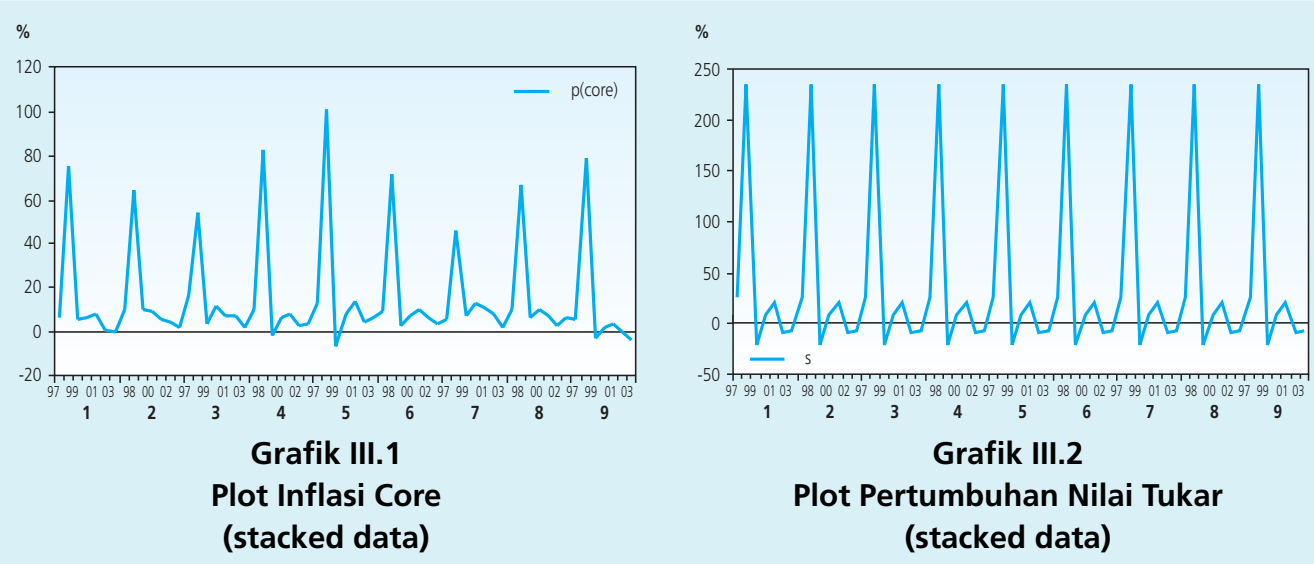

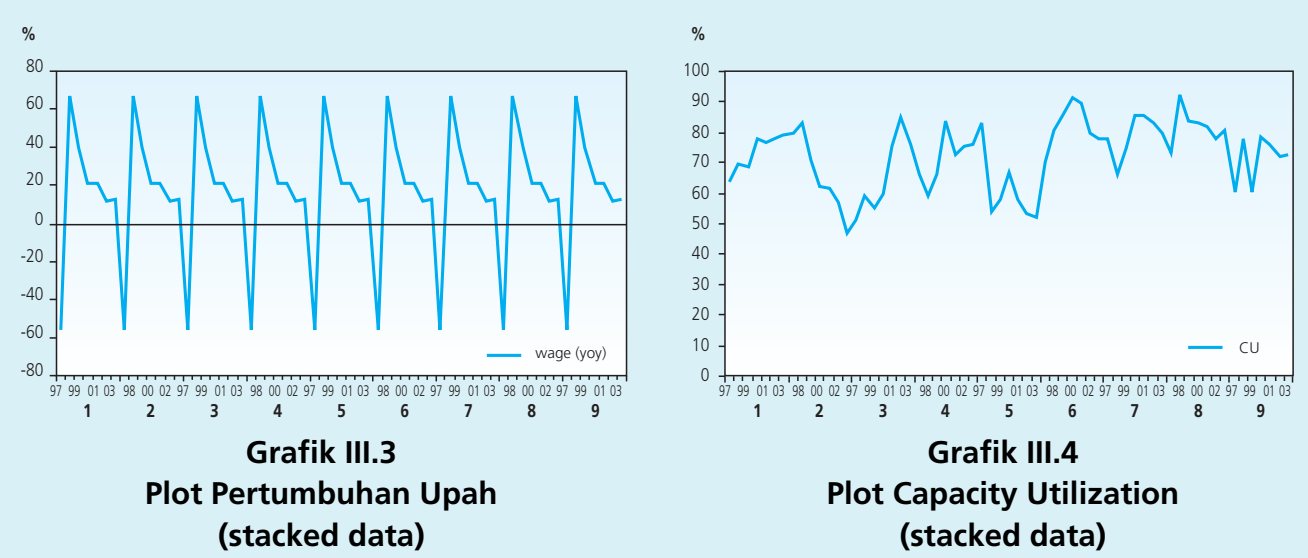

Berdasarkan plot data tersebut, terlihat bahwa pergerakan inflasi core tiap subsektor memiliki pola yang sama. Terdapat kenaikan inflasi yang sangat tinggi pada periode 1998 yang disebabkan oleh adanya krisis nilai tukar. Hal ini mengindikasikan dua hal terhadap hasil estimasi yang akan dilakukan. Pertama, besarnya peranan nilai tukar tehadap pergerakan inflasi core pada periode estimasi kemungkinan akan menyebabkan tingginya signifikansi estimated parameter untuk variabel nilai tukar. Kedua, adanya kesamaan pola pergerakan inflasi core subsektor kemungkinan akan menyebabkan estimated parameter yang menggambarkan karakteristik sub sektor tidak memiliki signifikansi yang tinggi, atau dengan kata lain tiap subsektor dapat diasumsikan memiliki karakteristik yang sama. Kedua hal ini akan diselidiki lebih lanjut dengan estimasi empiris pada bagian selanjutnya.

\section{HASIL DAN ANALISIS}

\section{IV.1. Hasil Estimasi}

Hasil estimasi persamaan (V.45) dengan menggunakan metode fixed effect pada periode 1997-2003 memperlihatkan bahwa capacity utilization pada tahun sebelumnya memiliki pengaruh positif terhadap pergerakan inflasi core tahun ini, namun tingkat signifikansinya hanya pada level 10\%. Hasil estimasi persamaan (V.45) dituliskan pada persamaan (V.47) berikut (nilai dalam kurung memperlihatkan t-statistic):

$$
\begin{gathered}
\Delta \pi_{i t}=-0.08+0.161 C U_{i t-1}+0.307 \Delta s_{i t}+0.075 \Delta \text { wage }_{i t-1} \\
(-1.42)(1.904)
\end{gathered}
$$

$$
\begin{array}{rlr}
\text { dengan } \alpha_{1}=-0.0025 & \alpha_{6}=-0.0089 & \mathrm{R} 2=0.93089 \\
\alpha_{2}=0.0020 & \alpha_{7}=-0.0312 &
\end{array}
$$




$$
\begin{array}{ll}
\alpha_{3}=0.0081 & \alpha_{8}=-0.0081 \\
\alpha_{4}=0.0117 & \alpha_{9}=-0.0293 \\
\alpha_{5}=0.0583 &
\end{array}
$$

Rendahnya nilai t-satistic pada estimasi parameter variabel $C U(-1)$ dapat disebabkan oleh adanya ambang batas (threshold) pada variabel $C U(-1)$ yang mempengaruhi dependent variable $\Delta \pi$, sehingga memasukkan semua series $C U(-1)$ sekaligus akan berakibat pada kurang signifikannya pengaruh variabel tersebut. Di samping itu t-statistic untuk estimated intercept juga sangat rendah.

Selanjutnya dilakukan estimasi persamaan (V.46) untuk mencari nilai threshold optimum atau tingkat NAICU dengan $C U^{*}$ bernilai 65 sampai dengan 90. Koleksi hasil estimasi memperlihatkan bahwa estimasi dengan sum of squared residual yang terkecil ditemukan pada nilai $C U^{*}=80$, sehingga threshold untuk nilai $C U$ ialah 80 . Persamaan hasil estimasinya ialah sebagai berikut (nilai dalam kurung memperlihatkan t-statistic):

$$
\begin{aligned}
& \Delta \pi_{i t}=-0.009+0.042\left(C U_{i t-1}<80\right)+0.102\left(C U_{i t-1} \geq 80\right)+0.305 \Delta s_{i t}+0.064 \Delta \text { wage }_{i t-1}
\end{aligned}
$$

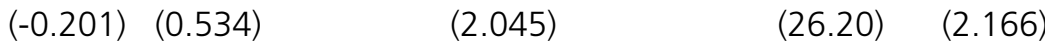

$$
\begin{array}{rlr}
\text { dengan } \alpha_{1}=0.0080 & \alpha_{6}=-0.0149 & \mathrm{R} 2=0.93425 \\
\alpha_{2}=0.0053 & \alpha_{7}=-0.0329 & \\
\alpha_{3}=0.0014 & \alpha_{8}=-0.0157 \\
\alpha_{4}=0.0132 & \alpha_{9}=-0.0199 \\
\alpha_{5}=0.0555 & &
\end{array}
$$

Dari persamaan (V.48) terlihat bahwa variabel capacity utilization yang pada tahun sebelumnya melewati level $80 \%$ memiliki pengaruh positif terhadap pergerakan inflasi core tahun ini dengan tingkat signifikansinya pada level 5\%. Sementara itu variabel capacity utilization yang pada tahun sebelumnya di bawah level $80 \%$ tidak signifikan dalam mempengaruhi pergerakan inflasi core tahun ini. Kondisi ini dapat digambarkan pada gambar berikut.

Gambar 1a memperlihatkan hubungan antara capacity utilization dengan perubahan inflasi dengan parameter intercept bernilai negatif, sehingga capacity utilization di bawah tingkatl NAICU akan menurunkan laju inflasi sementara capacity utilization di atas tingkat NAICU akan mempercepat laju inflasi. Di lain pihak Gambar 1b, memperlihatkan bahwa capacity 


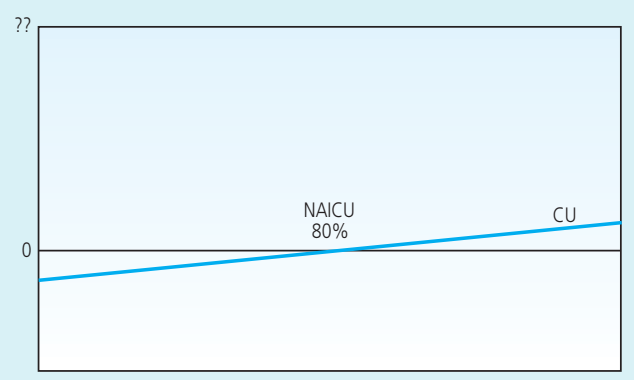

Gambar V.1a

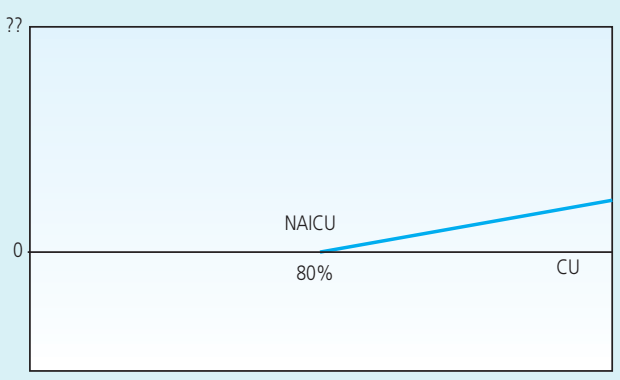

Gambar V.1b

utilization dibawah tingkat NAICU tidak akan mempengaruhi besarnya laju inflasi. Terkait dengan estimasi persamaan (47) maupun (48), tidak signifikannya estimasi parameter intercept dan parameter pada CU < 80 memperlihatkan hubungan seperti pada Gambar 1b, di mana capacity utilization di bawah 80\% tidak signifikan mempengaruhi pergerakan inflasi.

Sementara itu dari hasil estimasi NAICU, jika dibandingkan dengan hasil studi pengukuran NAICU di negara lain, tingkat NAICU sektor industri pengolahan Indonesia tidak jauh berbeda (Tabel V.1). Namun perlu diingat bahwa tingkat NAICU pada studi tersebut ialah berdasarkan hasil survey yang pada umunya berangkat dari konsep engineering approach, sementara tingkat NAICU pada studi ini ialah berdasarkan dual cost atau economic approach yang jelas memberikan hasil yang berbeda. ${ }^{7}$

\begin{tabular}{|c|c|c|c|c|c|c|}
\hline Country & \multicolumn{2}{|c|}{$\begin{array}{c}\text { Periode 1* } \\
\text { NAICU t-stat ( } p \text {-value) }\end{array}$} & \multicolumn{2}{|c|}{$\begin{array}{c}\text { Periode } 2 * * \\
\text { NAICU t-stat ( } p \text {-value) }\end{array}$} & \multicolumn{2}{|c|}{$\begin{array}{c}\text { Whole Sample } \\
\text { Coef on CU t-stat ( } p \text {-value) }\end{array}$} \\
\hline Germany & 83.0 & 1.4 & 84.9 & 2.4 & 0.03 & 2.3 \\
\hline France & 83.4 & 3.6 & 86.4 & 1.0 & 0.07 & 2.8 \\
\hline Netherland & 81.7 & 3.4 & 83.6 & 0.6 & 0.04 & 2.4 \\
\hline Belgium & 76.9 & 2.4 & 78.9 & 0.6 & 0.05 & 2.6 \\
\hline Italy & 73.4 & 4.3 & 78.1 & 3.3 & 0.09 & 2.9 \\
\hline UK & - & - & 83.3 & 3.3 & 0.15 & 5.3 \\
\hline US & 83.2 & $(.00)$ & 83.1 & $(.65)$ & 0.31 & $(.00)$ \\
\hline \multicolumn{7}{|c|}{$\begin{array}{l}\text { ** Periode } 2 \text { Germany, France, Netherland, Belgium and Italy : 1986:1-1996:4 } \\
\text { UK : 1982:2-1996:4 } \\
\text { US : 1983:1-1996:1 } \\
\text { Sumber: Nahuis (2003) dan Emery dan Chang (1997) }\end{array}$} \\
\hline
\end{tabular}

7 Untuk lebih jelasnya lihat Dwi Tjahjono, Husman dan Sianipar (2005). 


\section{IV.2. Pengujian Hipotesa}

Pada bagian ini akan dilakukan beberapa uji menyangkut estimasi persamaan (V.47) dan (V.48) uji tersebut ialah (i), uji Hausman-test untuk validasi pemilihan metode fixed effect, (ii) uji validasi pemilihan metode fixed effect untuk melihat apakah model dengan cross-section fixed effect merupakan model yang tepat. ${ }^{8}$ dan terakhir (iii) setelah spesifikasi model sudah tepat dilakukan uji hipotesa eksistensi dari efek threshold

a. Uji Hausman-test

Pertama-tama persamaan (V.45) diestimasi dengan menggunakan model random effect untuk kemudian hasil estimasi diuji dengan menggunakan Hausman test untuk melihat ketepatan pemilihan model. Hasil uji Hausman-test tersebut terlihat pada Tabel V.2 berikut:

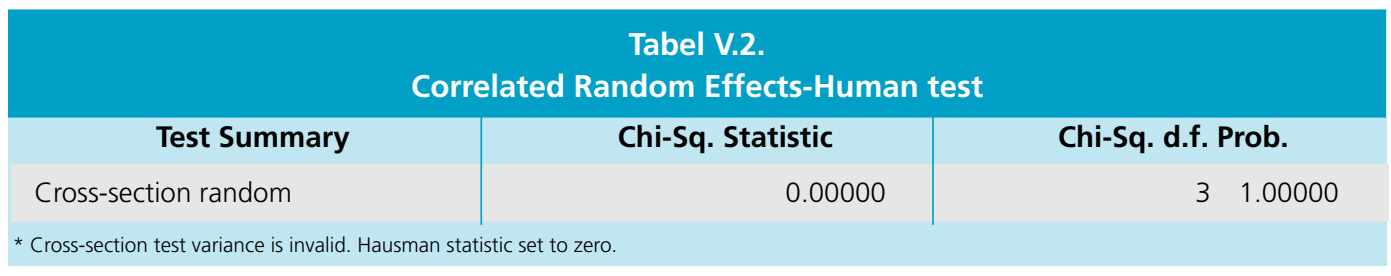

Berdasarkan hasil uji tersebut terlihat bahwa Hausman test statistic tidak dapat dikalkulasi sehingga diset bernilai nol. Hal ini dapat disebabkan oleh tidak signifikannya individual invariant effect, $\alpha_{i}{ }^{9}$. Untuk menguji apakah terdapat individual effect maka persamaan (V.45) akan diestimasi menggunakan metode fixed effect terlebih dahulu yang kemudian akan diuji apakah cross-section fixed effect pada spesifikasi model redundant atau tidak dengan menggunakan fixed effect test (Chamberlain, 1984).

\section{b. Uji Fixed Effect-test}

Pertama-tama persamaan (V.45) diestimasi dengan menggunakan metode cross-section fixed effect sehingga menghasilkan persamaan (V.47). Kemudian dilakukan uji fixed effecttest untuk menguji secara bersama-sama (joint significance) signifikansi dari fixed effect estimator. Hasil fixed effect-test tersebut terlihat pada Tabel V.3, berikut:

\begin{tabular}{|c|c|c|c|}
\hline \multicolumn{4}{|c|}{$\begin{array}{c}\text { Tabel V.3. } \\
\text { Redundant Fixed Effects Test } \\
\text { Cross-section fixed effect }\end{array}$} \\
\hline Effects Test & Statistic & d.f. & Prob. \\
\hline $\begin{array}{l}\text { Cross-section F } \\
\text { Cross-section Chi-square }\end{array}$ & $\begin{array}{l}0.917719 \\
8.473022\end{array}$ & $\begin{array}{r}(8,51) \\
8\end{array}$ & $\begin{array}{l}0.5097 \\
0.3887\end{array}$ \\
\hline
\end{tabular}

\footnotetext{
Untuk lebih jelasnya mengenai fixed effect test lihat Baltagi (2001)

Lihat Baltagi (2001) halaman 65.
} 
Dari hasil uji tersebut terlihat bahwa null hypothesis adanya redundant fixed effect tidak dapat ditolak (p-value 0.5097 dan 0.3887). Sehingga hasil uji ini mendukung dugaan dari hasil uji sebelumnya mengenai tidak adanya individual fixed effect pada struktur pool. Berdasarkan hal tersebut maka komponen akan dikeluarkan dari persamaan (V.45) sehingga persamaan (V.45) dan (V.46) akan diestimasi kembali menggunakan metode Pooled Least Square biasa. Hasil estimasi tersebut dapat dilihat pada persamaan (V.49) dan (V.50) berikut, masing-masing untuk persamaan tanpa threshold dan dengan threshold (nilai dalam kurung memperlihatkan t-statistic).

$$
\Delta \pi_{i t}=0.051 C U_{i t-1}+0299 \Delta s_{i t}+0.062 \Delta \text { wage }_{i t-1}
$$

$$
\mathrm{R} 2=0.920258
$$

Selanjutnya, dari hasil estimasi threshold dengan nilai 65 sampai dengan 90, terpilih kembali tingkat CU $80 \%$ sebagai threshold optimum yang memiliki nilai sum of squared residual terkecil. Hasil estimasi persamaan dengan threshold optimum ialah:

$$
\begin{aligned}
\Delta \pi_{i t}= & 0.013\left(C U_{i t-1}<80\right)+ \\
& (1.252) \\
\mathrm{R} 2= & 0.924649
\end{aligned}
$$

Pada dasarnya hasil estimasi (V.49) dan (V.50) tidak terlalu berbeda dengan (V.47) dan (V.48) kecuali bahwa estimated parameter pada variable capacity utilization menjadi lebih kecil dari 0.102 pada (V.48) menjadi 0.076 pada (V.50). Namun demikian tingkat NAICU tetap sama dan estimated parameters untuk kedua variabel lainnya tidak terlalu jauh berbeda dari estimasi awal menggnakan cross-section fixed effect. Hasil estimasi dengan metode Pooled Least Squared ini mengkonfirmasi Gambar 1b. sebagai gambar yang lebih tepat dalam menjelaskan hubungan antara capacity utilization dengan pergerakan inflasi.

\section{Uji Signifikasi Threshold}

Setelah threshold untuk nilai CU didapat pada nilai 80, akan dibuktikan apakah pengaruh threshold tersebut cukup signifikan. Hipotesa yang akan diuji adalah

$$
\begin{aligned}
& H_{0}: \gamma_{1}=\gamma_{2} \\
& H_{1}: \gamma_{1} \neq \gamma_{2}
\end{aligned}
$$

Nilai statistik $F^{*}$ (likelihood ratio) untuk persamaan (V.51) yang didapat dari hasil estimasi persamaan (V.49) dan (V.50) ialah 13.824 yang merupakan nilai likelihood ratio untuk threshold optimal. Selanjutnya dilakukan prosedur bootstrap untuk mendapatkan distribusi nilai likelihood ratio threshold, $\mathrm{F}_{\mathrm{th}}$ dengan 1000 kali pengulangan. 
Berdasarkan koleksi hasil prosedur bootstrap untuk nilai $\mathrm{F}_{\text {th }}$, maka $\mathrm{p}$-value untuk $\mathrm{F}_{\mathrm{th}}>\mathrm{F}^{*}$ ialah 0.005, sehingga threshold untuk nilai $\mathrm{CU}^{*}=80$ terbukti signifikan bahkan pada tingkat keyakinan $?=1 \%$. Hal ini memvalidasi tingkat NAICU industri pengolahan pada level $80 \%$.

\section{IV.3. Analisa Parameter Estimasi}

Pada persamaan (V.49) maupun (V.50) terlihat bahwa estimated parameter pada variabel nilai tukar memiliki nilai terbesar jika dibandingkan dengan estimated parameter dari variabel upah maupun variabel capacity utlization. Jika dilihat dari pola pergerakan data (lihat GrafikV.1) terlihat bahwa lonjakan pada tahun 1998 yang ditandai oleh adanya krisis ekonomi yang pada mulanya merupakan krisis nilai tukar, menyebabkan lonjakan pada inflasi core pada tahun yang sama (Grafik V.2). Masuknya periode krisis dalam periode estimasi ini agaknya menyebabkan variabel nilai tukar menjadi variabel yang dominan dalam menjelaskan pergerakan inflasi core, mengingat periode estimasi yang cukup pendek. Dengan adanya variabel nilai tukar ini, tidak dibutuhkan lagi variabel dummy untuk menangkap periode krisis.

Namun demikian, terlepas dari keterbatasan dari sisi periode estimasi, besarnya pengaruh nilai tukar dalam pergerakan inflasi ini sejalan dengan beberapa hasil studi pergerakan inflasi seperti misalnya pada Majardi (2000), Darsono, Majardi dan Hartawan (2002). Model pada studi terbut memperlihatkan bahwa elastisitas inflasi terhadap nilai tukar memiliki nilai yang cukup tinggi sehingga pass-through effect yang dihasilkan juga cukup besar. Kondisi ini memperlihatkan tinnginyanya pass-through nilai tukar ke dalam inflasi core, khususnya untuk direct pass-through. Studi lain oleh Warjiyo dan Agung (2002) dan Astiyah (2005) mengenai transmisi kebijakan moneter di Indonesia juga memperlihatkan signifikansi exchange rate channel yang kuat, bahkan Astiyah (2005) yang mengukur peran relatif antar channel transmisi moneter memperlihatkan bahwa exchange rate channel, terutama direst-pass through, memiliki peran yang terkuat.

Untuk melihat besarnya kontribusi masing-masing variabel penjelas terhadap pergerakan inflasi, dilakukan dekomposisi fitted value yang dibandingkan dengan nilai aktualnya. Grafik V.3 memperlihatkan dekomposisi tersebut untuk data agregat industri pengolahan setiap tahunnya. Dari gambar tersebut terlihat bahwa pergerakan nilai tukar memang memiliki kontribusi terbesar dalam pergerakan inflasi, terutama pada tahun 1998 saat terjadinya krisis nilai tukar. Sementara itu terlihat bahwa variabel capacity utilization hanya berkontribusi pada pergerakan inflasi core tahun 2001 dimana pada tahun itu tingkat capacity utilization sektor industri pengolahan (yang merupakan tingkat CU pada tahun 2000) telah mencapai tingkat NAICU pada level $80 \%$. Pada tahun tersebut variabel capacity utilization bahkan memberikan 
kontribusi yang terbesar dalam pergerakan inflasi, yaitu mencapai lebih dari 40\% dari pembentukan inflasi. Pada periode lainnya variabel capacity utilization tidak secara signifikan berkontribusi dalam pergerakan inflasi karena tingkat capacity utilization sektor industri pengolahan masih berada di bawah tingkat NAICU. Di lain pihak variabel upah memberikan kontribusi terbesarnya pada tahun 2000 (yang merupakan data kenaikan upah pada 1999 karena variabel upah memiliki lag satu). Pada periode tersebut telah terjadi kenaikan upah yang cukup tinggi yaitu mencapai 39.9\%. Pada tahun sebelumnya, varaibel upah juga mengalami pertumbuhan yang tinggi, namun pengaruh kenaikan variabel upah masih lebih kecil jika dibandingkan dengan pengaruh apresiasi nilai tukar sebesar $20 \%$ yang menyebabkan turunya inflasi core pada tahun 1999 tersebut.

Pola pergerakan inflasi core dengan capacity utilization dapat dilihat dari Grafik V.4. Pada grafik tersebut inflasi core diplot bersama dengan tingkat capacity utilization pada satu tahun sebelumnya. Dari grafik tersebut terlihat bahwa inflasi core sektor industri pengolahan meningkat pada saat tingkat capacity utilization sektor industri pengolahan melampaui tingkat NAICU, yaitu pada tahun 2001. Namun demikian terlihat bahwa pada tahun 2000 terjadi peningkatan inflasi dibandingkan tahun sebelumnya meskipun tingkat capacity utilization tahun sebelumnya masih dibawah tingakat NAICU. Naiknya laju inflasi berdasarkan model empiris yang digunakan, disebabkan oleh depresiasi nilai tukar rupiah dan tingginya kenaikan upah tenaga kerja sektor industri pengolahan. Di lain pihak untuk tahun 1999, 2002 dan 2003, inflasi core tidak mengalami kenaikan dan hal ini sejalan dengan tingkat capacity utilization yang masih berada di bawah tingkat NAICU-nya.
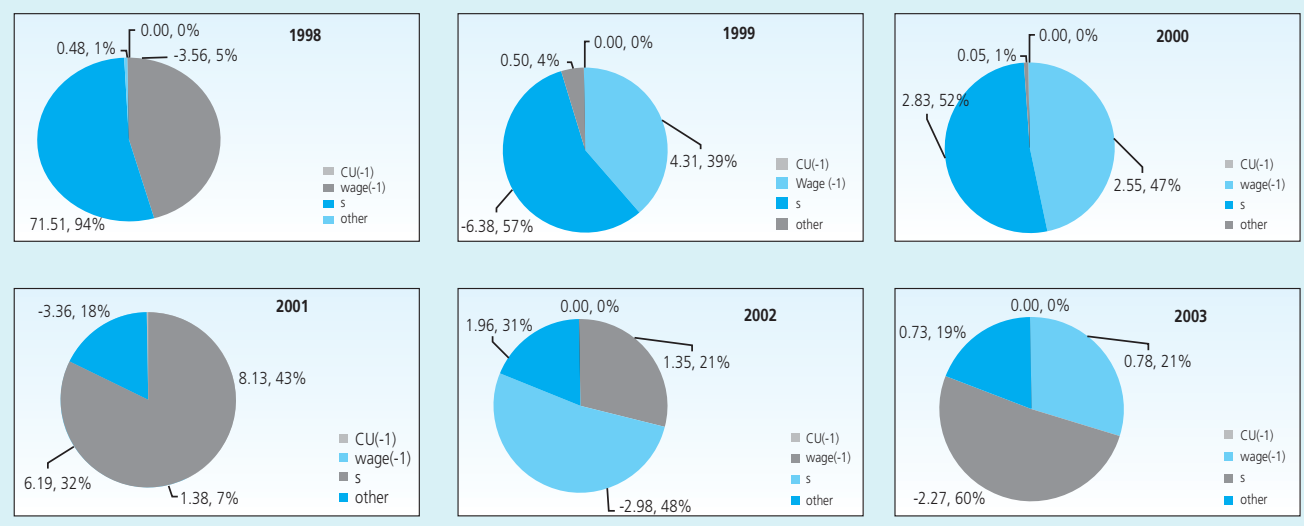

Grafik V.5

Kontribusi Variabel Penjelas dalam Pergerakan Inflasi Inti 


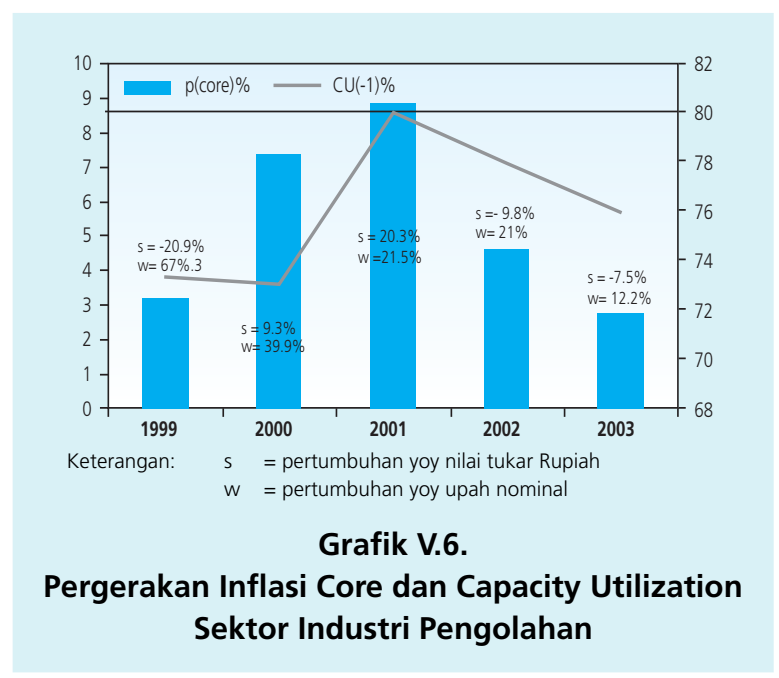

\section{KESIMPULAN}

Hasil pengukuran NAICU berdasarkan Dual Cost Capacity Utilization menggunakan metode threshold non-dynamic panel data memperlihatkan bahwa terdapat threshold pada tingkat capacity utilization $80 \%$ dengan tingkat keyakinan $\alpha=1 \%$, sehingga NAICU untuk sektor industri pengolahan ialah pada tingkat $80 \%$. Berdasarkan hasil estimasi, tingkat capacity utilization di atas tingkat NAICU akan menyebabkan meningkatnya akselerasi inflasi core, sementara capacity utilization di bawah tingkat NAICU tidak memiliki pengaruh yang signifikan terhadap inflasi core. Efek dari peningkatan capacity utilization ini akan terealisasi pada inflasi tahun berikutnya. Hasil estimasi pada studi ini juga memperlihatkan bahwa nilai tukar memiliki peranan tertinggi dalam pergerakan inflasi. Hal ini utamanya terkait dengan periode estimasi yang mencakup periode krisis nilai tukar pada 1998.

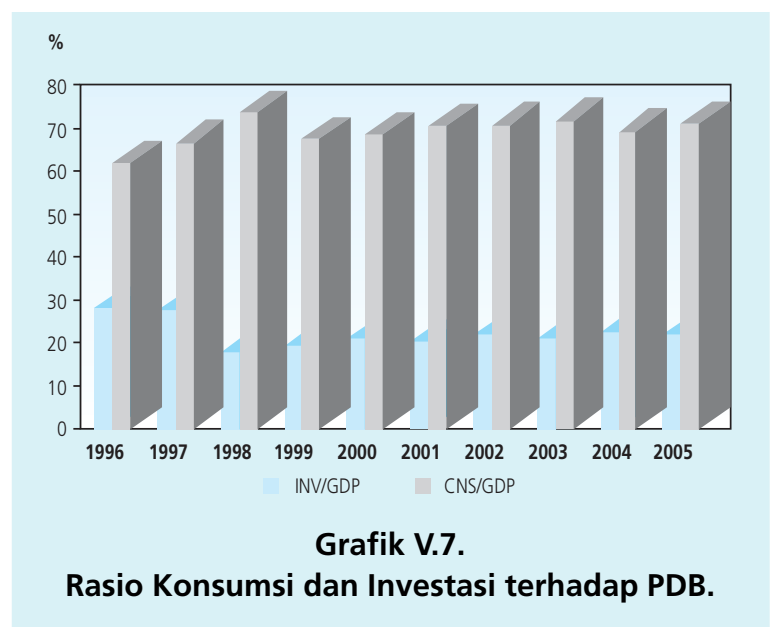


Terkait dengan target inflasi Bank Indonesia yang cenderung menurun untuk 2006, 2007 dan seterusnya, terdapat beberapa hal yang perlu untuk diperhatikan:

- Tingkat dual cost capacity utilization pada 2005 diproyeksikan mencapai $76 \%$ yang merupakan peningkatan secara perlahan-lahan dibandingkan tahun-tahun sebelumnya.

- Di lain pihak, perkembangan investasi yang masih melambat dapat menyebabkan naiknya tingkat CU di 2006, jika diasumsikan permintaan aggregat, khususnya konsumsi, tetap meningkat (Grafik V.7).

- Berdasarkan hal tersebut disarankan agar kebijakan moneter pada tahun 2006 masih cenderung tight bias. Kebijakan penurunan suku bunga harus dilakukan secara berhati hati agar dapat meminimasi inflationary consequences yang mungkin terjadi mengingat "accommodating policy might be more inflationary when capacity is high" (Dotsey dan Stark, 2005). 


\section{DAFTAR PUSTAKA}

Astiyah, Siti, "Pemetaan dan Peran Relatif Jalur Transmisi Kebijakan Moneter Paska Krisis", Biro Riset Ekonomi Bank Indonesia Occasional Paper, 2005.

Baltagi, Badi H., Econometric Analysis of Panel Data, Second Edition, John Wiley \& Sons Ltd., West Sussex, England, April 2002.

Bank Indonesia, Quaterly Macroeconomic Model, Directorate of Economic Research and Monetary Policy, 2003.

Darsono; Fadjar Madjardi dan Arif Hartawan," Small Scale Macro Model - Extended", Directorate of Economic Research and Monetary Policy bank Indonesia Working Paper, 2002.

Dotsey, Michael and Stark, Thomas," The Raltionship Between capacity Utilization and Inflation" Federal Reserve Bank of Philladephia Business Review, Second Quarter 2005, pp. 8-17.

Emery, Kenneth M.; and Chang, Chih-Ping, "Is There a Stable Relationship Between Capacity Utilization and Inflation?" Federal Reserve Bank of Dallas Economic Review, First Quarter 1997, pp. 14-20.

Gordon, Robert J.,"The Theory of Domestic Inflation", American Economic Review, February 1977, Papers and Proceedings, 67, 128-34.

Economic Activity, 1977, 8:1, pp. 253-77

," The Time-Varying NAIRU and its Implications for Economic Policy" The Journal of Economic Perspectives ${ }_{L}$ vol. 11, No. 1 (Winter 1997), pp. 11-32

Gordon, Robert J., Stephen R. King dan Franco Modigliani," The Output Cost of Disinflation in Traditional and Vector Autoregressive Models," Brookings Papers on Economic Activity, 1982, 13:1, pp. 205-42.

Gujarati, Damodar, Basic Econometrics, Prentice Hall, 4 ${ }^{\text {th }}$ Edition, 2003.

Hansen, Bruce E. "Tresshold effects in non-dynamic panels: Estimation, testing, and inference", Journal of Econometrics, 1999, 93, pp 345-368

Khan, M.S., and Abdelhak S. Senhadji,"Threshold Effects in the Relationship between Inflation and Growth," IMF Staff Paper, Vol 48:1, 2001. 
Laksono, Beta Yulianita Gitaharie, "Identifikasi Jalur Mekanisme Transmisi Kebijakan Moneter dalam Mencapai Tingkat Inflasi yang Mendukung Pertumbuhan Ekonomi" ,Disertasi, Program Pasca Sarjana, Fakultas Ekonomi Universitas Indonesia, 2004

Mankiw, Gregory, Macroeconomics, fifth edition, Worth Publishers, New York 2002.

Majardi, Fadjar, "Dampak Pergerakan Nilai Tukar Rupiah terhadap Laju Inflasi di Indonesia", Gema Korps Bank Indonesia, 2000, Vol. 29.

Nahuis, Niek J. "An alternative demand indicator: the 'non-acclerating inflation fate of capacity utilization" Applied Economics, 2003, 35, pp. 1339-1344

Rich, Robert W.; and Rissmiller, Donald; " Understanding the Recent Behaviour of U.S. Inflation" Federal Reserves Bank of New York Current Issues in Economics and Finance July 2000

Tjahjono, Endy D; Jardine A. Husman, dan Deshy V.B. Sianipar,"Pengukuran Capacity Utilization Berdasarkan Pendekatan Dual Cost pada Industri Pengolahan di Indonesia"Biro Riset Ekonomi Bank Indonesia, 2005

The World Book Dictionary (1994), Vol. 2 L-Z, Clarence L. Barnhart and Robert K. Barnhart (editors), Chicago: World Book, Inc.

Warjiyo, Perry and Juda Agung"Transmission Mechanism of Monetray Policy in Indonesia", Directorate of Economic Research and Monetary Policy, Bank Indonesia, 2002. 
